\title{
The Poetic Utilization of Dialectal Varieties of the Afrikaans Language for Strategic Purposes in the Southern African Context
}

\begin{abstract}
Afrikaans is a southern African language named after the continent on which it has evolved from seventeenth-century Dutch in a complex contact situation between European settlers, their imported slaves, and indigenous peoples. It was standardized in the late nineteenth and early twentieth centuries for literary purposes, among others. The poetic utilization of dialectal or colloquial varieties of Afrikaans, however, has been an important trend in its literary history, especially since the advent of the so-called Movement of the 1960s. The relevant varieties include geolects like Karoo Afrikaans, but also sociolects like "Loslitafrikaans" (informal Afrikaans, characterized by being mixed with English), Cape Afrikaans, and Griqua Afrikaans. As a stylistic device, the use of dialectal Afrikaans has served both literary-strategic purposes (literary renewal) and socio-political aims (as actuality literature or socio-politically engaged poetry). As a whole, it transpires that the pressing socio-political and broader cultural conditions that have dictated past developments, or are driving present ones, in South and southern Africa (resistance to nineteenth-century efforts at anglicizing southern Africa, the advent and decline of Apartheid, the increasingly hegemonic position of English in the post-Apartheid dispensation) loom large behind the relative importance of this trend in Afrikaans poetry.
\end{abstract}

Keywords: actuality, Afrikaans geolects and sociolects, socio-political and cultural conditions, socio-political engagement, strategic poetic utilization, stylistic renewal

\section{Introductory notes on the origins of the Afrikaans language and literature}

Afrikaans is a southern African language, named after the continent on which it originated. It evolved from seventeenth-century Dutch in the contact situation between European settlers, their slaves of East African and South-East Asian descent, and the indigenous African peoples in what was later known as the Cape of Good Hope. The latter became a British colony in 1806. Efforts at anglicizing its inhabitants contributed to the circumstances under which two republics were es- 
tablished to the north of the colony by white Afrikaans-speaking settlers, who came to call themselves Afrikaners or Boers. Another result was that the Afrikaners appropriated Afrikaans as a symbol of their identity, specifically during the last quarter of the nineteenth century (the era of the First Afrikaans Language Movement), when they endeavoured to shape the language into an effective medium for literary and other cultural expressions (Steyn 2014, 19-41).

After the Anglo-Boer War (1899-1902), during which the two Boer republics had been devastated by Britain, renewed anglicization efforts ensued. This inspired Afrikaners to cultivate their language anew (Second Afrikaans Language Movement). In the process of standardizing Afrikaans, modern Dutch was often taken as a model (Steyn 2014, 154-179). In this way, Afrikaans was prepared for recognition as an official language, next to English from 1925, of a unified South Africa - a geopolitical dispensation dominated by its white citizens. In this context, it was deemed the natural task of the young Afrikaans writers to refine the language into an instrument capable of registering subtleties of both individual and national consequence (Steyn 2014, 62-204). Nearly a hundred years later, the Afrikaans literary system has grown to be at least doubly as extensive as its South African English counterpart (Giliomee 2004, 628; Galloway and Venter 2016, 452).

\section{Towards typologies of colloquial varieties of Afrikaans and their poetic functions}

In the period in the wake of the Second Afrikaans Language Movement, sometimes referred to as a "third movement" (1934-1955; cf. Kannemeyer 2005, 120), ${ }^{1}$ the ideals for the literary utilization of the standardized language were expressly cast in the mould of the highest aesthetic considerations (Opperman 1953, 13). This era, however, also produced an early example of a poet turning to one of Afrikaans's dialects for poetic purposes. Incorporating traits of so-called Griqua Afrikaans in some of his poems, S. J. Pretorius effectively enhanced the authenticity of his portrayal of realities pertaining to the arid, north-western parts of South Africa (Britz 1999, 474). The regional and communal focus in these poems by Pretorius was transformed into a much more prominent trend in Afrikaans poetry after 1955. The issue of poetry written in Afrikaans as an African language, but

1 All translations in this article are my own. 
also the socio-political realities confronting the citizens of Apartheid South Africa, became important discursive constructions in the poetry of that era (Kannemeyer 2005, 269). One expression of this trend was an increased use of colloquial or vernacular Afrikaans - a phenomenon which will be the focal point of the rest of this investigation.

"Colloquial varieties of Afrikaans" means forms of the language in which the regional origin or the social group context of its speakers manifests itself (Carstens 2003, 289-292). These include geographic dialects (geolects, or regional language forms), social dialects (sociolects, or group language forms), and ethnic dialects (ethnolects). The colloquial language trend in Afrikaans poetry was introduced by the poets Boerneef and N. P. van Wyk Louw in the early 1950s. In some of their poems, they made use of the so-called Bokkeveld geolect of the region of their upbringing (Steyn 2014, 336). Soon, the ethnolect of the so-called Cape coloured people also came to be employed - with great satirical effect in protesting against the Apartheid system and the hegemonic position of standardized Afrikaans, both championed by the ruling Afrikaners. Interestingly, three white poets (Peter Blum, R. K. Belcher, and Uys Krige) belong to this early group of protesters. The most important among them, however, was Adam Small, a so-called coloured man.

As will be shown, more "Cape Afrikaans" poets came to the fore in due course, as did more poetic utilizers of the aforementioned Griqua-Afrikaans and other regional forms of the language. "Loslitafrikaans" - literally "loose-jointed," or informal Afrikaans, characterized by being mixed with English - was another colloquial variety employed to express anti-hegemonic sentiments. After the end of the Apartheid dispensation in 1994, the new South African ideal of inclusivity has come to play a major role in the growing value placed on poetry written in non-standardized forms of Afrikaans.

Even from this provisional overview, what becomes apparent is that the poetic use of colloquial varieties of Afrikaans seems to have certain distinct functions. There are, firstly, socio-political reasons for their utilization. They can serve as expressions of regional or group identities and realities, which then, in a sense, earmark such poetry as belonging to what can be labelled as "actuality literature," that is, literature in which the evocation of a recognizable part of reality predominates (Brink 1992, 39). Such poetry may, however, also serve to support or to embody socio-political protest or ideological criticism. Its characteristics then lean towards those of purpose-literature or engaged literature, from which it is apparent that poets stand as antagonists of conservative societal powers, striving to transform them (Brink 1992, 40). Alternatively, literary strategic designs may be pursued by using colloquial language varieties. As a stylistic element, this can contribute to effecting poetic renewal. It can, however, also constitute a "facet of 
subversive aesthetics," for instance by foregrounding social relevancy or temporality instead of "universality" or "general validity" as aesthetic values (Willemse 1999, 11-12).

This typology of functions, and the colloquial language categories distinguished above, will be employed in a brief depiction of the poetic utilization of colloquial Afrikaans varieties since the mid-1950s.

\section{Approaching the 1960s}

An outstanding theme in the work of a number of Afrikaans poets who may be seen as forerunners of the so-called Poets of the 1960s was what can be described as a (re)discovery of the South African reality, including actualities like the sociopolitical position and accompanying life experiences of the "coloured people" of South Africa (Opperman 1974, 116-117).

The name of Peter Blum needs to be mentioned again. Being a European immigrant to South Africa, he took a relatively independent stance towards the Afrikaans poetry tradition. He offered a "cutting and questioning" view (Foster 2000) of South African realities of the time, specifically as manifested in Afrikaans communities. He was an early exploiter of Cape Afrikaans in a number of "Kaapse sonnette" [Cape sonnets]. Socio-political aims and ideological criticism clearly speak from these poems, amplified by an accompanying element of aesthetic subversion.

Boerneef (pseudonym of I. W. van der Merwe), a poet also referred to before, contributed significantly in this regard by exploring the colloquial language usage and cultural expressions of, among others, the farming communities of the Karoo region of South Africa (Van der Merwe 1981, 1). Style and form were poetic means by which he made the disparities between the actualities of farm and city life manifest. More important, however, is the status Boerneef attained by these means as a stylistic innovator in the Afrikaans poetry system.

\section{The movement of the 1960s}

The literary historiographer J. C. Kannemeyer (2005, 285-291) identifies the coloured poet Adam Small as one of the most important annunciators of an "intensified social conscience" which manifested itself in much of the work by Afrikaans poets debuting in the 1960s. In Small's poems, often written in Cape Afrikaans, the collective protest sentiments of the Afrikaans-speaking coloured community came to be expressed poignantly. Taking a satirical approach, he exposed the un- 
tenability of the Apartheid system and the "false values" of its "authoritative figures" (Van Wyk 2007).

George Weideman's passionate love for the arid regions of Namaqualand, Bushmanland, and the Richtersveld in South Africa was expressed in the fields of reference and imagery he employed. It also came to the fore in his playfully creative use of the Afrikaans vernacular of those regions (Van Coller and Odendaal 1999,767 ) - adding to the status of an important part of his poetic production as actuality literature.

\section{After the socio-political upheaval of 1976 in South Africa}

1976 was the year in which violent revolts against the Apartheid system flared up in the black townships of South Africa. One result was that Afrikaans became associated with the Apartheid system and the effects of humiliation it had on the non-white majority of the population - a result that is felt to this day (Van Vuuren 1999, 247).

Contrary to the stigmatization of the language, Afrikaans itself increasingly came to be employed in the literary struggle which ensued against Apartheid. From the late 1970s, a number of poetry anthologies were published in which "struggle verse" in Afrikaans was included, mainly by coloured poets and in the vernacular of the Cape Flats, a suburban region to the north of the city of Cape Town. These coloured poets saw themselves as contributors to "Black Consciousness poetry," which did not "primarily serve an aesthetic purpose, but a pragmatic one" (Foster 2000; emphasis in original). They therefore positioned themselves as being in "protest against the process of homogenizing, co-opting and ethnic chauvinism" (Foster 2000). Hence, a struggle spokesman like Ikey van de Rheede (1983, 33) could ponder whether the poetic use of the Cape coloured vernacular had also earned Afrikaans an advantageous status as a language of protest and liberation (in contrast to the label of language of the oppressor that it usually carries).

Even defenders of struggle poetry would admit that most such political resistance poetry lacked artistic appeal, rarely transcending the specific socio-political context in its effect. Established Afrikaans publishers of the era were seldom prepared to publish such works; the struggle poets often had to find alternative ways to make their work known. Clinton V. du Plessis's œuvre is an example of this. He continues his practice of self-publication to this day, arguing that the Afrikaans literary system is still dominated by a "master narrative" of whiteness (see Adendorff 2003, 77). 
Although the political protest element is not absent from his Cape "street poetry" (Kannemeyer 2005, 674), the three collections published by Peter Snyders between 1982 and 2002 show more strongly the features of actuality literature insofar as the focus in them is on the portrayal of the everyday life of the coloured people of South Africa. The latter is also true of the most recent poetry collections by Marius Titus; in his poetry, the experience of the continued peripheral position of coloured people in post-Apartheid South Africa is verbalized with biting irony.

\section{Systemic democratization and the inclusion of formerly marginalized voices in Afrikaans poetry since 1990}

Two trends in Afrikaans poetry from the post-Apartheid era seem to be conducive to the growing status of colloquial varieties of the language. The first entails the democratization of the system, in unison with the political emancipation of South African society since the ban on black political organizations was lifted in 1990, which led to the establishment of a new South African dispensation under the presidency of Nelson Mandela in 1994; the second is the marked foregrounding of the need to give voice to the marginalized (Foster 2000). One expression of such trends is the strategy of changing the image of Afrikaans literature. In poetry, this is demonstrated by the Afrikaans translations of poetry from indigenous African languages undertaken by the highly praised poet Antjie Krog (Odendaal 2006, 138-139).

The repeatedly expressed need for more (and new) non-white voices in Afrikaans poetry (Almano 2001; Burger 2002; Adendorff 2003, 101-102; De Jager 2005) is another manifestation of these trends. Similar to the situation in the 1980s, some coloured poets turn to self-publication to make their voices heard (Adendorff 2003, 101-102; Crous 2009, 200). Others, however, are having collections released by established publishers, reaping prestigious literary awards for some (Odendaal 2015, 53). A further current manifestation of such foregrounding of poetry written by members of previously marginalized groups (Adendorff $2003,52-53)$, is the publication of quite a number of group or occasional anthologies.

An important aspect of the democratization and inclusion trends therefore seems to be the growing presence of colloquial Afrikaans varieties as a language of poetry, even in literature for children (De Wet 2005, 45). Telling evidence in this regard are literary-historical anthologies of Afrikaans poetry compiled in the late 
1990s. In both Gerrit Komrij's Die Afrikaanse poësie in 'n duisend en enkele gedigte [Afrikaans Poetry in a Little More Than a Thousand Poems] (1999b) and André P. Brink's Groot verseboek 2000 [Great Book of Verse] (2000b), a deviation is visible from the anthologies edited by D. J. Opperman, compiler of earlier versions of the Groot verseboek. Brink (2000a, i-iii) is explicitly of the opinion that Opperman's modernization of the spelling of nineteenth-century poetic texts, as well as his handling of colloquial Afrikaans poetry by the likes of the aforementioned Peter Blum, Adam Small, and Boerneef, constituted a resignation to the ideology of Afrikaner nationalism with its centralization of standardized Afrikaans. Both Brink and Komrij express their wish to reflect "something of the roots of Afrikaans poetry" as well as of its "unadornedness" and "vitality" (Komrij 1999a, 6-8) in their compilations. They afford much more space to poetry in colloquial varieties of the language than Opperman did, for example by including poems from the First Afrikaans Language Movement in "the original written forms, thereby linking up with the delightful variety of afrikaans versions (without the capital letter) written by younger generations" (Brink 2000a, iv).

From the present state of affairs in the system, one can conclude that the process of the canonization of poetry in colloquial forms of Afrikaans, in support of the transformation sought for in the broader cultural system, has been largely consummated (see Odendaal 2006, 136-137). Literary-strategic aims - which are, however, effects of new socio-political ideals - have been, at least partly, realized in this manner.

\section{A few remarks on the appearance of colloquial varieties of Afrikaans in the work of individual poets after 1990}

The number of instances where Afrikaans vernacular forms from the arid, northwestern parts of South Africa and from Namibia have been utilized by poets has shown an increase since 1990 (Odendaal 2015, 43-46). To mention but one example: the Griqua-Afrikaans used by Hans du Plessis in important parts of his poetic œuvre has produced some of the greatest commercial successes in the history of Afrikaans poetry publication (Kannemeyer 2005, 693). As an expert on sociolinguistics and language politics, he has expressed himself repeatedly in favour of an inclusive approach to Afrikaans and its colloquial varieties. He also questions the differentiation between "communal art" forms and "high" or elitist art (Coetzee 2002, 7). The successes achieved by Du Plessis's Griqua poetry are based on the striking versification and imagery that characterize it, but also on the humor- 
ous effects of the tensions created between the elevated (addressing of the biblical God) and the "mundane" (the earthly vernacular and unsophisticated world of reference of the Griqua subjects in his poems; see Van Zyl [2001, 9]).

The term "Loslitafrikaans," mentioned earlier, indicates what the leading Afrikaans poet Antjie Krog has depicted, in an interview with Anstey (1999, 11), as “a lekker [nicely] Anglicised Afrikaans," spoken by persons whose mother tongue is, in fact, standardized Afrikaans. A deliberate insubordination to, or nonchalance towards, the standard norms is implied. The latter is indicative of the marginal lifestyle, subversive of societal conventions, portrayed by the likes of André Letoit (also known as Koos Kombuis) and Gert Vlok Nel in their work (see Keyser 1999, 16; Kannemeyer 2005, 649).

Recent forms of Cape Afrikaans verse include collections by the Cape "street poet” Loit Sôls (Weideman 1998, 2), and the award-winning Ronelda S. Kamfer and Nathan Trantraal (the latter two also a married couple). The need they feel for socio-political engagement plays an important role in these poets' decision to use the Cape Afrikaans vernacular in their work. The stereotype of the "Happy Hotnot" [Happy Hottentot] mentality, for instance, is irrevocably "bombed apart" by Kamfer (2008). However, she also goes on to show that, in spite of the antagonisms that have been effected by the injustices of the past, South Africans have more to share than they have reasons to continue their divisions. In her poetry, Kamfer reflects something of both the divisions experienced and the heritages shared by South Africans by employing language varieties that have played a role in identity formation in her own (pre-)history: standardized Afrikaans, Cape Afrikaans (with tatters of English mixed into it), fragmented Dutch, and Islamic-Arabian.

The marked autobiographical strain of Nathan Trantraal's Chokers and Survivors (2013) may be seen as both an authenticating and an actualizing strategy (Odendaal 2013a). As a stylistic device, his use of Cape Afrikaans serves as a kind of embodiment of the life experiences he strives to verbalize. Because he considers himself to be a choker of the "ghetto" (Trantraal 2013), he has the ability to be an authentic interpreter of those circumstances, characterized by a suffocating lack of prospects and lawlessness. The latter claims form the basis of some scathing attacks Trantraal made on the legacy of poets such as Peter Snyders and Adam Small (Cape Afrikaans not being their home language; see Marais [2013]). To his mind, the likes of Small and Snyders have made a joke-language of Cape Afrikaans - a curiosity of the literary system (Odendaal 2013b). Quite a number of polemicists, however, have pointed out his error of judgement in this regard (see Odendaal 2015, 48).

Trantraal's tirade must also be judged against the background of the homages and literary awards bestowed on Small during the past few years (among others, 
the prestigious Hertzog Prize for Afrikaans drama). Trantraal has accused Small and Snyders of not voicing the destitution of the speakers of Cape Afrikaans with sufficient urgency. From certain utterances by Trantraal, it becomes clear that he actually is of the opinion that - in light of the conciliation sought within the ranks of the broader Afrikaans-speaking community - Small has been so strongly centralized in the Afrikaans literary system that he can scarcely be seen as an authentic interpreter of the position of the marginalized any longer (see Burger 2014).

It is the actualities of the group which he represents that are of primary importance to Trantraal. The conclusion cannot be avoided, however, that literarystrategic considerations also play their part in his thinking. With his claim that he and Kamfer are the poets fit to be the true interpreters of the actualities of the Cape coloured people, and by voicing a disdain for the contributions of strongly canonized figures (particularly Small), he is apparently seeking to pave the way for stronger positionings by him and his wife in the current Afrikaans poetry system.

\section{Conclusions}

"We write as we speak" was the "fundamental axiom" (Dekker 1967, 13) which S. J. du Toit, a leader in the First Afrikaans Language Movement, formulated with respect to the ideals of white Afrikaners in the late nineteenth century.

More than a hundred years later, the poet Nathan Trantaal (2014) echoes Du Toit's view with very similar wording: "Write it as you say it." The parallels suggested between a trend from the era of the First Afrikaans Language Movement and one from the post-1994 South African dispensation, are not entirely out of place. Efforts towards transforming the Afrikaans literary system in order to render it more inclusive of the various communities in South Africa are coherent with the tolerance demonstrated towards, even the wish for, poetry written in the different colloquial varieties of the language. In fact, the drive for inclusion is linked to a broader cultural striving for a situation where all speakers of Afrikaans will take ownership of the language, especially in a current context which is not conducive to the maintenance of the language in its higher functions (Steyn 2014, 444-448, 452-464).

Next to purposes of literary renewal, poetry written in dialects or colloquial language varieties almost invariably serves to accentuate group or regional identities (Schneibel 2009; Sanderson 2012, 1). The socio-political implications of this - through the various sociolinguistic values represented by such colloquial varieties - are seldom lacking. With reference to Afrikaans poetry, the shadows of the "pressing reality" (Roodt 1991, 3) of the South African socio-political context 
reach over just about every instance of the use or promotion of its vernacular varieties, whatever the (intended) effects. Clearly, Afrikaans people do not only write poetry in the same style as they speak the language; they also write in the manner they wish to be heard by one another.

\section{Works cited}

Adendorff, E. M. “Digdebute teen die millenniumwending: 'n Polisistemiese ondersoek” [Poetry Debuts towards the Millennial Turn: A Polysystemic Investigation]. MA diss. University of Stellenbosch, 2003.

Almano, Ada. “'Swart' Afrikaanse digters en 'n omvattende, inklusiewe Suid-Afrikaanse digkuns: 'n Posisiebepaling" ["Black" Afrikaans Poets and a Comprehensive, Inclusive South African Poetry: A Position Determination]. MA diss. University of the Western Cape, 2001.

Anstey, Gillian. "When the Truth Hurts the Heart." Sunday Times 23 May 1999: 11.

Brink, André P. "Betrokke literatuur” [Literature of Engagement]. Literêre terme en teorieë [Literary Terms and Theories]. Ed. T. T. Cloete. Pretoria: HAUM-literêr, 1992. 38-41.

Brink, André P. "Vooraf gespeel” [Played Beforehand]. Groot verseboek 2000 [Great Book of Verse 2000]. Comp. Brink. Cape Town: Tafelberg, 2000a. i-vi.

Brink. André P., comp. Groot verseboek 2000 [Great Book of Verse 2000]. Cape Town: Tafelberg, 2000b.

Britz, E. C. "S. J. Pretorius (1917-1995)." Perspektief en profiel: 'n Afrikaanse literatuurgeskiedenis [Perspective and Profile: A History of Afrikaans literature]. Ed. H. P. van Coller. Vol. 2. Pretoria: Van Schaik, 1999. 473-486.

Burger, Bibi. "Die plesiere van die kanon" [The Pleasures of the Canon]. Slipnet. 2014. http:// slipnet.co.za/view/event/die-plesiere-van-die-kanon (6 November 2014).

Burger, Willie. "Waar's die nuwe stemme in ons letterkunde?" [Where Are the New Voices in Our Literature?]. LitNet. 2002. http://www.litnet.co.za/waars-die-nuwe-stemme-in-ons-letterkunde-2002 (23 February 2017).

Carstens, W. A. M. Norme vir Afrikaans: Enkele riglyne by die gebruik van Afrikaans [Norms for Afrikaans: Some Guidelines for the Usage of Afrikaans]. 4th ed. Pretoria: Van Schaik Publishers, 2003.

Coetzee, Gert. "Alle kuns is kuns; alle Afrikaans is Afrikaans - Du Plessis” [All Art Is Art; All Afrikaans Is Afrikaans - Du Plessis]. Volksblad 22 April 2002: 7.

Crous, Marius. “Afrikaans Poetry: New Voices.” Current Writing 21.1-2 (2009): 200-217. http:// www.ajol.info/index.php/cw/article/view/52619 (23 February 2017).

De Jager, Nèlleke. "Waar is die nuwe generasie swart Afrikaanse skrywers?" [Where Is the New Generation of Black Afrikaans Writers?]. LitNet. 2005. http://www.litnet.co.za/waar-is-dienuwe-generasie-swart-afrikaanse-skrywers-2005 (23 February 2017).

Dekker, Gerrit. Afrikaanse literatuurgeskiedenis [Afrikaans Literary History]. 12th ed. Cape Town: Nasou, 1967.

De Wet, Karen. "Afrikaanse kinder- en jeugpoësie sedert 1970" [Afrikaans Children's and Youth Poetry since 1970]. Van Patrys-hulle tot Hanna Hoekom: 'n Gids tot die Afrikaanse kinder- en jeugboek [From Patrys and Friends to Hanna Hoekom: A Guide to the Afrikaans Children's and Youth Book]. Ed. Gretel Wybenga and Maritha Snyman. Pretoria: LAPA, 2005. 41-55. 
Foster, Ronel. "Beelde van die Afrikaanse poësie sedert 1960" [Images of Afrikaans Poetry since 1960]. LitNet: PoetryNet. 2000. http://www.oulitnet.co.za/poesie/09beelde.asp (22 February 2017).

Galloway, Francis, and Rudi Venter. "Die Afrikaanse uitgewersbedryf” [The Afrikaans Publishing Industry]. Perspektief en profiel: 'n Afrikaanse literatuurgeskiedenis [Perspective and Profile: A History of Afrikaans Literature]. Ed. H. P. van Coller. Vol. 3. Pretoria: Van Schaik, 2016. 365-557.

Giliomee, Hermann. Die Afrikaners: 'n Biografie [The Afrikaners: A Biography]. Cape Town: Tafelberg, 2004.

Kamfer, Ronelda S. Noudat slapende honde [Now that Sleeping Dogs]. Rogge Bay: Kwela Books, 2008.

Kannemeyer, J. C. Die Afrikaanse literatuur 1652-2004 [Afrikaans Literature 1652-2004]. Cape Town and Pretoria: Human \& Rousseau, 2005.

Keyser, Gawie. “Hy verpersoonlik eerlikheid” [He Personifies Honesty]. Afrikaans vandag [Afrikaans Today] 6.2 (March 1999): 16.

Komrij, Gerrit. "Woord vooraf” [Introductory Word]. Die Afrikaanse poësie in 'n duisend en enkele gedigte [Afrikaans Poetry in a Little More Than a Thousand Poems]. Comp. Komrij. Amsterdam: Bakker, 1999a. 5-9.

Komrij, Gerrit, comp. Die Afrikaanse poësie in 'n duisend en enkele gedigte [Afrikaans Poetry in a Little More Than a Thousand Poems]. Amsterdam: Bakker, 1999b.

Marais, Danie. "Konflik in 'n kanon" [Conflict in a Canon]. By [Supplement] 12 October 2013: 5.

Odendaal, B. J. "Tendense in die Afrikaanse poësie in die tydperk 1998 tot 2003" [Trends in Afrikaans Poetry in the Period 1998 to 2003]. Perspektief en profiel: ' $n$ Afrikaanse literatuurgeskiedenis [Perspective and Profile: A History of Afrikaans Literature]. Ed. H. P. van Coller. Vol. 3. Pretoria: Van Schaik, 2006. 105-148.

Odendaal, Bernard. "Chokers en survivors (Nathan Trantraal)" [Chokers and Survivors (Nathan Trantraal)]. Versindaba. 2013a. http://versindaba.co.za/2013/06/26/resensie-chokers-ensurvivors-nathan-trantraal (6 November 2014).

Odendaal, Bernard. "Klawerjas (Adam Small)" Vack of Clubs (Adam Small)]. Versindaba. 2013b. http://versindaba.co.za/2013/10/21/resensie-klawerjas-adam-small (6 November 2014).

Odendaal, B. J. “Omgangsvariëteite van Afrikaans in die digkuns sedert Sestig” [Colloquial Varieties of Afrikaans in Poetry since the 1960s]. Stilet 27.2 (2015): 32-62.

Opperman, D. J. Digters van Dertig [The Poets of the Thirties]. Cape Town: Nasionale Boekhandel, 1953.

Opperman, D. J. Naaldekoker [Needle-Case/Dragonfly]. Cape Town: Tafelberg, 1974.

Roodt, P. H. "Rondom die literatuur en kritiek van die tagtigerjare" [On the Literature and Criticism of the Eighties]. Stilet 3.1 (1991): 1-20.

Sanderson, Stewart. "Poems Chiefly in the Scottish Dialectic: Scots Poetic Translation and the Second Generation Modern Scottish Renaissance (c.1940-1981)." MPhil(R) thesis. University of Glasgow, 2012.

Schneibel, Gerhard. "Dialect Poetry in Translation Connects Regional Cultures across Europe." Deutsche Welle. 2009. http://www.dw.de/dialect-poetry-in-translation-connects-regionalcultures-across-europe/a-4778206 (7 November 2014).

Steyn, J. C. “Ons gaan 'n taal maak": Afrikaans sedert die Patriot-jare [“We're Going to Create a Language": Afrikaans Since the Years of The Patriot]. Pretoria: Kraal, 2014.

Trantraal, Nathan. Chokers en survivors [Chokers and Survivors]. Rogge Bayi: Kwela Books, 2013. 
Trantraal, Nathan. “Skryf 'it soes jy praat” [Write It Like You Say It]. LitNet. 2014. http://www. litnet.co.za/Article/poolshoogte-skryf-i-soes-jy-praat. (7 November 2014).

Van Coller, H. P., and B. J. Odendaal. “George Weideman (1947- ).” Perspektief en profiel: 'n Afrikaanse literatuurgeskiedenis [Perspective and Profile: A History of Afrikaans Literature]. Ed. Van Coller. Vol. 2. Pretoria: Van Schaik, 1999. 764-785.

Van de Rheede, Ikey. "Kommentaar oor enkele aspekte van 'Kleurling-Afrikaans”" [Comments on Some Aspects of 'Coloured Afrikaans']. Standpunte [Points of View] 36.6 (1983): 30-37.

Van der Merwe, C. N. Tromboniusdagboekenkaart: 'n Boerneef-boek [Trombonediaryandmap: A Boerneef Book]. Cape Town: Tafelberg, 1981.

Van Vuuren, Helize. “Perspektief op die moderne Afrikaanse poësie (1960-1997)” [A Perspective on Modern Afrikaans Poetry (1960-1997)]. Perspektief en profiel: 'n Afrikaanse literatuurgeskiedenis [Perspective and Profile. A History of Afrikaans literature]. Ed. H. P. van Coller. Vol. 2. Pretoria: Van Schaik, 1999. 244-304.

Van Wyk, Steward. "Die Groot Small - oor die lewe en werk van Adam Small” [The Great Small on the Life and Work of Adam Small]. LitNet. 2007. http://www.litnet.co.za/die-groot-smalloor-die-lewe-en-werk-van-adam-small/ (22 February 2017).

Van Zyl, Wium. “Innie skylte vannie Jirre (Hans du Plessis)" [In the Shelter of the Lord (Hans du Plessis)]. Die Burger [The Burgher] 16 July 2001: 9.

Weideman, George. “My straat en anne straat-poems (Loit Sôls)” [My Street and Other Street Poems (Loit Sôls)]. Radiosondergrense. 7 June 1998. Typescript supplied to the author.

Willemse, Hein. "'n Inleiding tot buite-kanonieke Afrikaanse kulturele praktyke" [An Introduction to Extra-Canonical Cultural Practices in Afrikaans]. Perspektief en profiel: ' $n$ Afrikaanse literatuurgeskiedenis [Perspective and Profile: A History of Afrikaans literature]. Ed. H. P. Van Coller. Vol. 2. Pretoria: Van Schaik, 1999. 3-20.

Bernard Odendaal teaches creative writing at the North-West University in South Africa. He is a rated South African researcher, a published poet, and a writer and translator of song texts used in various shows. His scholarly publications include fifty peer-reviewed journal articles and book chapters. A collection of his essays and column contributions were published in book format in 2016. 